\title{
Interaction Between the Warm Subsurface Atlantic Water in the Sermilik Fjord and Helheim Glacier in Southeast Greenland
}

\author{
Ola M. Johannessen • Alexander Korablev • Victoria Miles • \\ Martin W. Miles • Knut E. Solberg
}

Received: 21 January 2011/ Accepted: 13 May 2011

(C) The Author(s) 2011. This article is published with open access at Springerlink.com

\begin{abstract}
Recent observations of ocean temperature in several Greenland fjords suggest that ocean warming can cause large changes in the outlet glaciers in these fjords. We have observed the Helheim outlet-glacier front in the Sermilik Fjord over the last three decades using satellite images, and the vertical fjord temperature and salinity during three summer expeditions, 2008-2010. We show that the subsurface water below $250 \mathrm{~m}$ depth is the warm saline Atlantic Water from the Irminger Sea penetrating into the fjord and exposing the lower part of the Helheim glacier to warm water up to $4^{\circ} \mathrm{C}$. Lagged correlation analysis spanning the 30-year time series, using the subsurface Atlantic Water temperature off the coast as a proxy for the variability of the subsurface warm Atlantic Water in the fjord, indicates that $24 \%$ of the Helheim ice-front movement can be accounted for by ocean temperature. A strong correlation $(-0.75)$ between the ice-front position and the surface air temperature from a nearby meteorological station suggests that the higher air temperature causes melting and subsequent downward percolation of meltwater through crevasses leading to basal lubrication; the correlation accounts for $56 \%$ of the ice-front movement. The precise contribution of air temperature versus ocean temperature however, remains an open question, as more oceanographic and meteorological measurements are needed close to the glacier terminus.
\end{abstract}

O. M. Johannessen $(\bowtie) \cdot$ A. Korablev · V. Miles

Mohn Sverdrup Center for Global Ocean Research at Nansen Environmental and Remote Sensing Center, and Nansen Scientific Society, Thormøhlensgate 47, 5006 Bergen, Norway

e-mail: ola.johannessen@ nersc.no

M. W. Miles

Uni Research-Bjerknes Centre for Climate Research, 5007 Bergen, Norway

M. W. Miles

Institute for Arctic and Alpine Research, University of Colorado, Boulder, CO 80309, USA

K. E. Solberg

Fotspor.org, Oslo, Norway 
Keywords Greenland outlet glaciers · Ocean warming · Surface melting

\section{Introduction}

Recent observations suggest that major changes in the dynamics of Greenland outlet glaciers take place over time scales of years rather than several decades or centuries as previously believed (Truffer and Fahnestock 2007). Many studies have indicated that increased discharge rates of outlet glaciers are playing a significant role in mass loss from Greenland. For example, several large outlet glaciers doubled their discharge rates over 5 years, and in 1996, the annual ice loss was $91 \mathrm{~km}^{3}$, but in 2005 it had risen to $224 \mathrm{~km}^{3}$ (e.g., Rignot and Kanagaratnam 2006), though estimates depend on the period sampled. Satellite observations have also revealed apparent rapid changes in outletglacier discharge (Rignot and Kanagaratnam 2006), especially in southeast Greenlande.g., Helheim and Kangerdlugssuaq glaciers (Howat et al. 2007, 2008; Joughin et al. 2008) — as well as Jakobshavn glacier in west Greenland (Joughin et al. 2004; Holland et al. 2008) and Petermann glacier in north Greenland (Johannessen et al. 2011). Differences in mass-balance estimates arise partly from uncertainties in changes near the ice sheet margins, largely due to limited temporal sampling that provides only 'snapshots' (e.g., Rignot and Kanagaratnam 2006; Howat et al. 2007) rather than the range of variability.

The underlying mechanisms of recent outlet-glacier behavior remain unclear, although it has been suggested that regional oceanic and/or atmospheric warming, as well as local effects of downward percolating meltwater (Zwally et al. 2002; Andersen et al. 2010; Schoof 2010) are responsible. Separating the influence and importance of these forcing is challenging (Bamber et al. 2007), although it has been suggested (Bindschadler 2006) that the ocean plays a critical role, at least for outlet glaciers such as Jakobshavn glacier (Holland et al. 2008), Petermann glacier (Rignot and Steffen 2008; Johnson et al. 2011) and southeast Greenland glaciers, e.g., Helheim (Murray et al. 2010; Straneo et al. 2010).

Despite its importance in this context, Greenland waters-especially in the inner shelf areas and fjords-have been sparsely sampled with oceanographic measurements, such that the spatial-temporal variability is scarcely known. Repeated oceanographic measurements that are highly-resolved spatially are needed from the locations near the dynamic outlet glaciers, in order to explore two-way interactions. This includes hypothesized triggering of ice discharge and retreat at the terminus (Nick et al. 2009), such as from warm water reaching the grounding line. Here we will explore this hypothesis by investigating the fjord-water variability and glacier linkages in addition to the impact of surface air temperature on the melting of the Helheim glacier. We take advantage of a comprehensive 30-year record of ice-front variations, together with long time series of air and ocean water temperature, as well as new oceanographic cruise data from the Sermilik Fjord during three consecutive summers.

Section 2 addresses the different data sets used, including the position of the Helheim ice-front over the last 30 years, oceanographic stations measuring temperature and salinities down to several hundred metres in the Sermilik Fjord during summers 2008-2010 and offshore of the fjord for the same 30-year period as for the movement of the Helheim icefront, and surface air temperature in the region. In Sect. 3 we discuss the results and our preliminary conclusions. 


\section{Data}

\subsection{Helheim Glacier}

We have analysed the position of the Helheim glacier, Fig. 1, from CORONA, Landsat, SPOT and ERS 1-2 satellite images and have produced a 30-year continuous time series from 1980 to 2010 for August/September, Fig. 2. This represents a longer continuous record of interannual variability than previously published for this glacier (e.g., Howat et al. 2008; Joughin et al. 2008).

During 1999, 2000 and 2001, there were no significant seasonal variations of the Helheim ice-front, but from 2002 to 2010 the seasonal variations were 3-4 km (not shown), reaching a maximum retreat in August/September. During the period from 1980 to 2001, the centre of the ice-front first moved $4 \mathrm{~km}$ forward and after that $\pm 1-2 \mathrm{~km}$ back and forth, probably constrained by the sill depth of $550 \mathrm{~m}$ (Joughin et al. 2008). However, during the period from 2002 to 2005 , a substantial retreat of 7-8 km took place, thereafter advancing $3 \mathrm{~km}$ from 2005 to 2006 and again stabilizing for the following period including 2010 (Fig. 2, see also Fig. 7a for movement). It should also be mentioned that the two other outlet glaciers in the same fjord: Midgård and Fenris glaciers (Fig. 1) showed similar

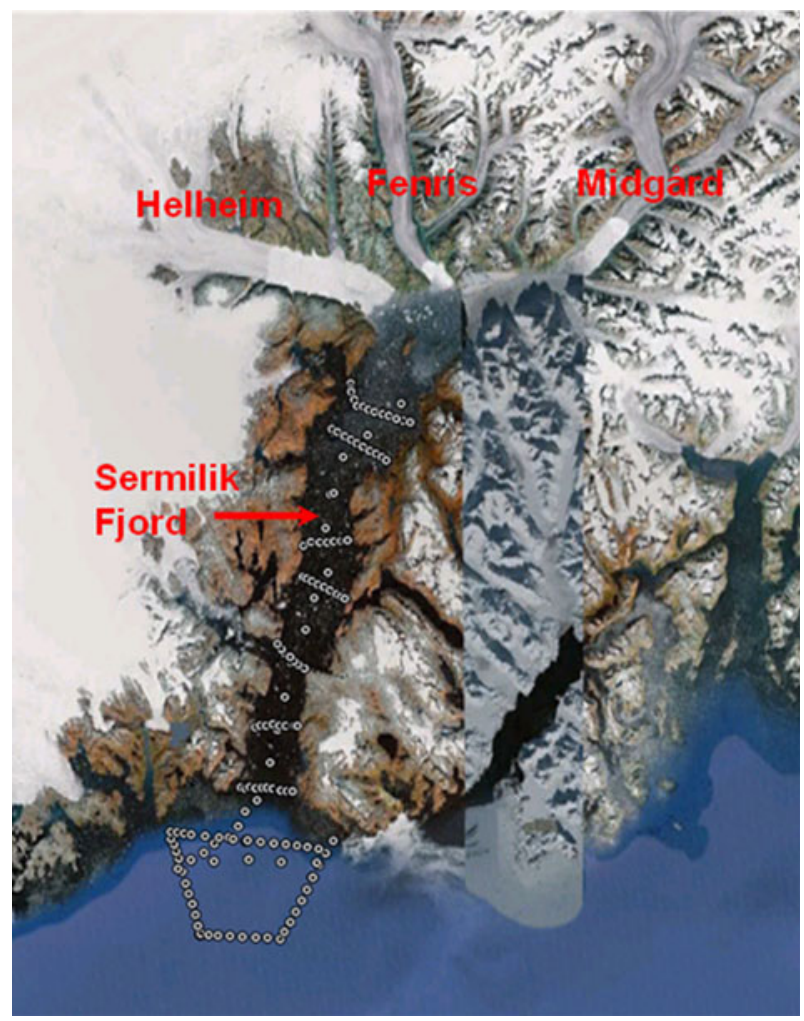

Fig. 1 Satellite image showing the outlet glaciers Helheim, Fenris and Midgård in the Sermilik Fjord. The CTD station positions in August 2009 are shown as white circles 


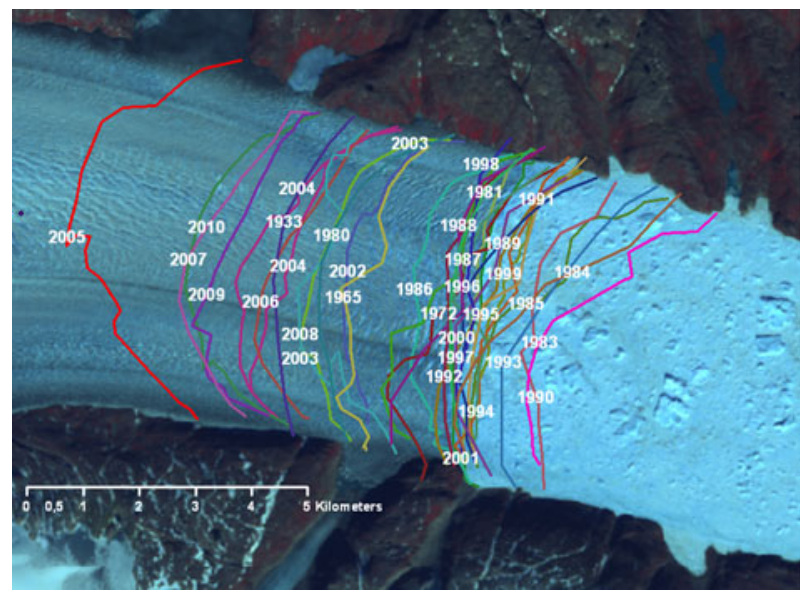

Fig. 2 Helheim glacier ice-front positions each year from 1980-2010, supplemented with a few earlier observations. The ice-front positions are derived from Corona, Landsat, SPOT and ERS 1-2 satellite images movement, suggesting that the forcing was the same, although this is not addressed further here.

\subsection{Fjord/Ocean Data}

Our hypothesis is that the subsurface fjord water of warm Atlantic origin (Straneo et al. 2010) melts the deeper part of the ice-front and the bottom part of the floating Helheim glacier which penetrates vertically several hundred metres in the fjord (Joughin et al. 2008), causing some of the movement of the Helheim ice-front, in the addition to the effect of surface melting with downward percolating meltwater causing lubrication at the base of the glacier at the bedrock (Zwally et al. 2002, Schoof 2010).

We have therefore carried out a multi-year series of summer expeditions in August to the Sermilik Fjord, performing temperature and salinity, measurement from the sailboat Jotun Arctic using a conductivity temperature depth (CTD) recorder with an accuracy of $0.01^{\circ} \mathrm{C}$ for the temperature and $0.02 \mathrm{psu}$ for the salinity down to $400 \mathrm{~m}$ in 2008 and to $600 \mathrm{~m}$ in 2009 and 2010. Navigation was done by using a GPS with accuracy of 5-10 m.

An example of the oceanographic stations is shown from 2009 in Fig. 1. As seen from Fig. 1, we were not able to penetrate all the way into the Sermilik Fjord to reach the Helheim ice-front, due to very heavy ice conditions caused by a large amount of drifting icebergs and seasonal fjord ice in the inner part of the fjord. The temperature and salinity sections from 2008, 2009 and 2010 (Fig. 3) show the fjord temperature and salinity structure. In general, a fjord circulation with a freshwater supply will have a low-salinity outflowing current in the surface layer of few metres thickness which requires an inflow further below, modified by wind, tides, internal waves (Johannessen 1968; Mernild et al. 2010) and offshore conditions on the shelf (Straneo et al. 2010). Our temperature and salinity sections from three summers, Fig. 3, show in general cold $\left(\sim 0^{\circ} \mathrm{C}\right)$ low-salinity water $(\sim 22 \mathrm{psu})$ in the surface layer, but below $200 \mathrm{~m}$ the water temperature was more than $2^{\circ} \mathrm{C}$, increasing to more than $3^{\circ} \mathrm{C}$ below $250 \mathrm{~m}$ depth and to more than $4^{\circ} \mathrm{C}$ at $300 \mathrm{~m}$ caused by inflow of warm saline Atlantic water up to $34.80 \mathrm{psu}$.

In 2008 and 2010 , the water temperature was $\sim 0.8-1.0^{\circ} \mathrm{C}$ higher at $400 \mathrm{~m}$ than in 2009 . Because the Helheim glacier is up to $800 \mathrm{~m}$ deep (Joughin et al. 2008), this means that the 

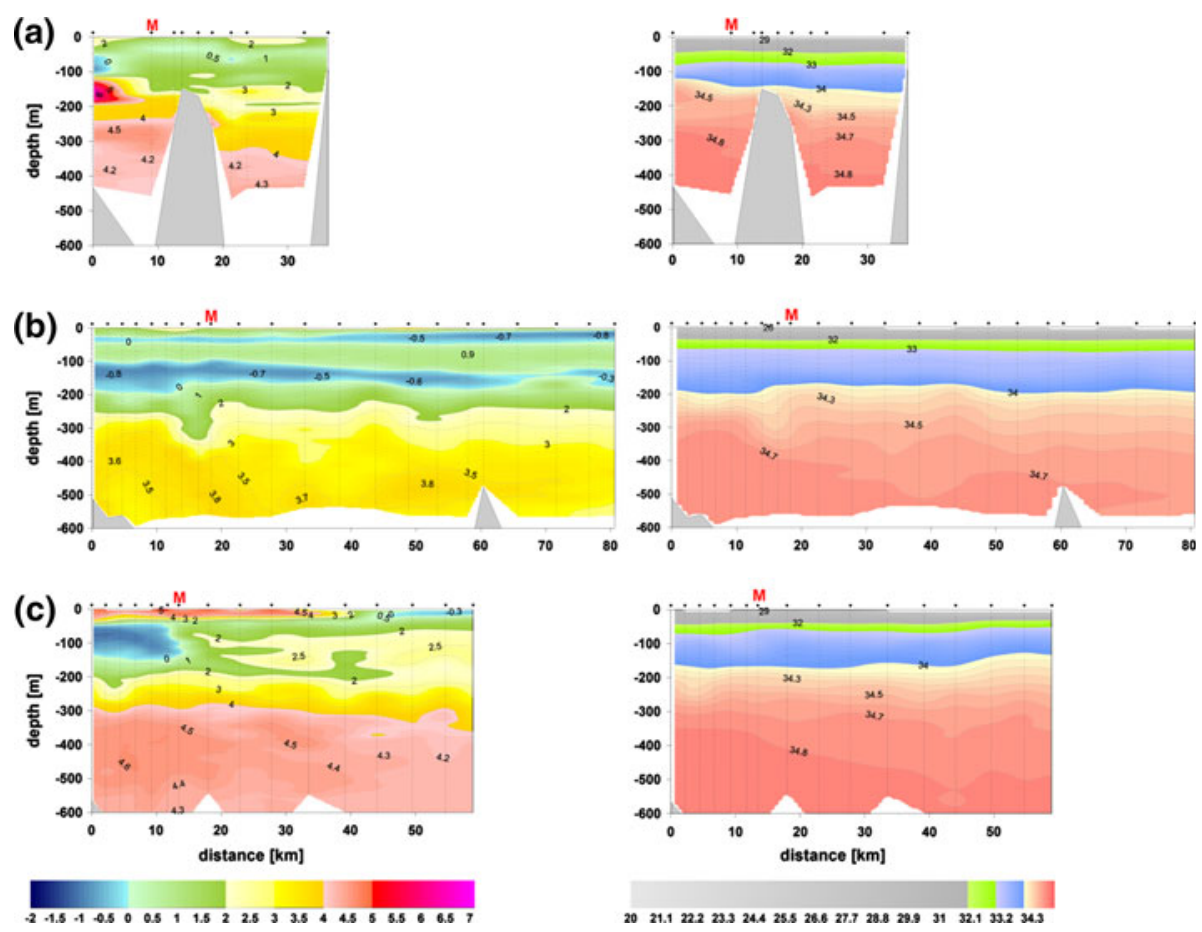

Fig. 3 Distributions of the potential temperature $\left({ }^{\circ} \mathrm{C}\right.$, left panel) and salinity (psu, right panel) along the Sermilik Fjord longitudinal sections obtained in August 2008 (a), 2009 (b) and 2010 (c). The sections from different years had different starting points and different lengths but are centred to the fjord mouth marked with red ' $\mathrm{M}$ '

lower part of the glacier is exposed to warm water with a temperature of up to $4^{\circ} \mathrm{C}$ causing submarine melting from below. This "bathing" from warm Atlantic water has probably gone on for thousands of years, but what is important for the bottom melting of the glacier is that the temperature of the inflowing warm Atlantic water can change from year to year, as we have seen from our three sections.

However, in order to perform a robust statistical analysis, longer time series of the warm subsurface Atlantic water-as well as surface air temperature from a nearby meteorological station-are needed to compare with our 30-year time series of the movement of the Helheim ice-front.

\subsection{Proxy for Warm Atlantic Water in the Fjord}

Fortunately, Argo floats exist for the areas off the coast of the Sermilik Fjord. As an example, the drift of one of the Argo floats (http://www.argo.net) gives profiles of temperature and salinity from the surface to $2,000 \mathrm{~m}$ depth after 10 days of drifting at $1,000 \mathrm{~m}$, as shown in Fig. 4.

This Argo float strongly indicates that it moves with the Atlantic water in the Irminger Current south of Iceland, then turns in the southern part of the Greenland-Iceland gap and thereafter hugging the Greenland continental shelf southwards (Fig. 4a). Thereafter it becomes grounded in the canyon across the shelf leading into the Sermilik Fjord. From the 
(a)

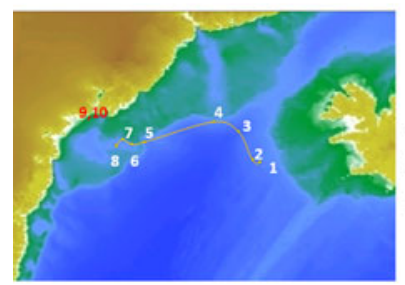

(b)

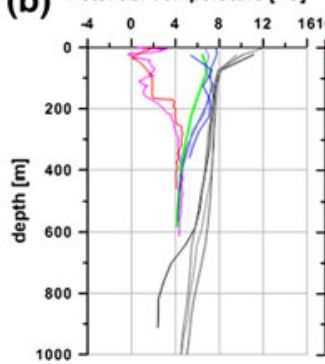

Potential Density [kg/m3]
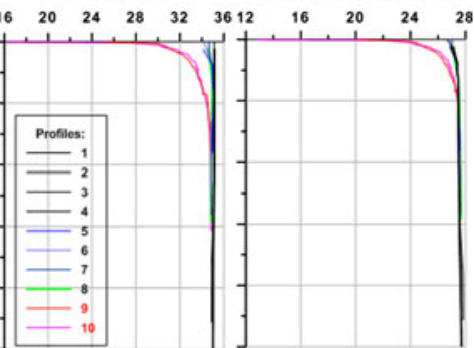

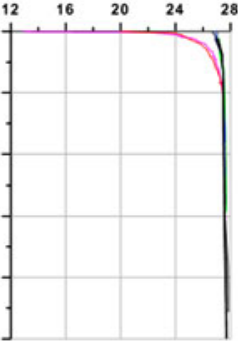

Fig. 4 a Consecutive position of the profiles (1-8) in the Irminger Sea and in a deep canyon over the Greenland shelf break as measured by Argo profiling float 6900452 from 04.07.2007 to 22.09.2007 and CTD stations $(9,10)$ in the Sermilik Fjord mouth. b Vertical profiles of the potential temperature, salinity and potential density for the positions numbered in a. Profiles for two CTD stations completed in the Sermilik Fjord mouth in August 2008 (red) and 2010 (magenta) inserted for comparison. Note that properties of the Atlantic Water were altered into fjord water below $300 \mathrm{~m}$ depth

vertical temperature and salinity profiles (Fig. 4b) it is seen that below $400 \mathrm{~m}$ the water in the canyon is more than $4^{\circ} \mathrm{C}$, indicating that this is how the warm and saline water enters the fjord-note the similarity to the T-S measurements from the entrance of fjord (red lines in Fig. 4b). This implies that the warm, saline Atlantic water "dives" under the southflowing East Greenland Current (EGC) and East Greenland Coastal Current (EGCC) because of its greater density (Fig. 4b). Therefore, Atlantic water in the Irminger Current is the source of the warm and saline subsurface water in the Sermilik Fjord, as shown schematically in Fig. 5.

We therefore assumed that the temporal variability of the temperature and salinity in the Irminger Current would also to some extent represent the temporal variability of the warm Atlantic water in the Sermilik Fjord. We therefore constructed a time series of all oceanographic stations back to 1970 (Fig. 6) and used this annual time series as a proxy for the variability of the fjord water at $400 \mathrm{~m}$ (Fig. 7b), albeit not as absolute values.

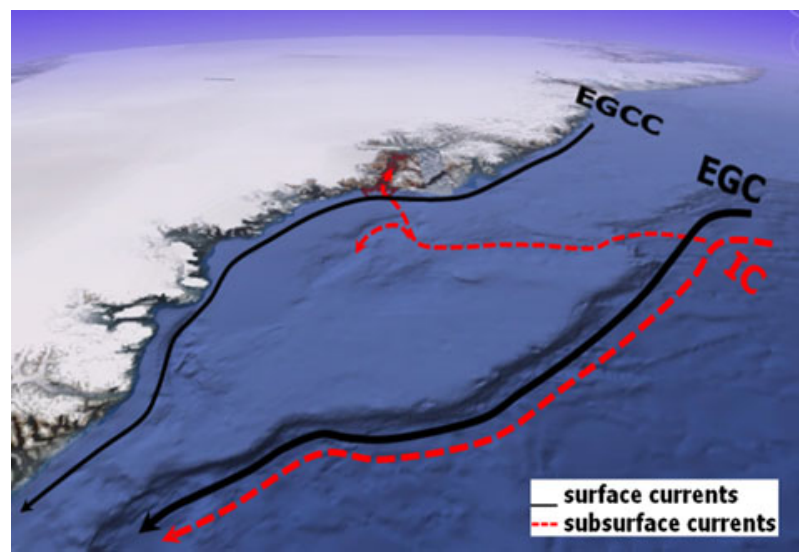

Fig. 5 Schematic of the major warm (red) and cold (black) currents over the Greenland shelf break and shelf including the East Greenland Current (EGC), East Greenland Coastal Current (EGCC) and Irminger Current (IC). The hypothesized trajectory of the Atlantic Water flowing from the shelf break through a canyon into the Sermilik Fjord is also shown 
Fig. 6 Position of the oceanographic stations 1970-2010 selected to construct water temperature time series for the Irminger Sea shown in Fig. $7 b$

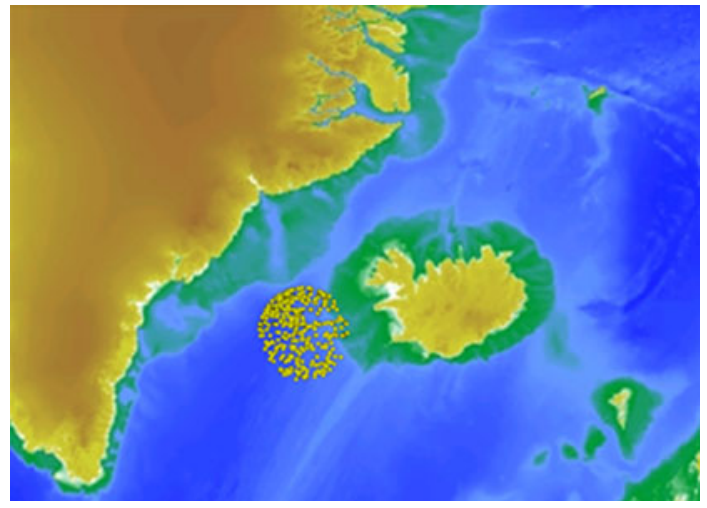

\subsection{Surface Air Temperature}

Surface air temperature (SAT) has been recorded at the Danish Meteorological Institute coastal station at Tasiilaq (http://climexp.knmi.nl) some 80-90 km east of the Helheim icefront (Fig. 7c). This is the closest station to Helheim glacier that has a long record of measurements.

\section{Results and Conclusions}

\subsection{Results}

The long-term variability of the Helheim ice-front, as well as the variability of the fjord water temperature proxy and the SAT are shown in Fig. 7.

In studying the three curves qualitatively, it is clearly seen that when the Helheim icefront retreated substantially during the period from 2001 to 2005 (Figs. 2, 7a), both the fjord water temperature proxy at $400 \mathrm{~m}$ (Fig. 7b) and the air temperature (Fig. 7c) were increasing, suggesting some linkage. Figure 7 also indicates that all three variables exhibit a shift to a new equilibrium state in the 2000s.

In order to study this more quantitatively, we carried out an exploratory statistical analysis. (We note that the proxy fjord temperature is about $2^{\circ} \mathrm{C}$ higher than observed in the fjord, but stress that in our analysis we are interested in the co-variability and not necessarily the absolute temperature values.) In our statistical analysis, we performed lagged cross-correlations between the ice-front movement with the proxy fjord temperature and found a maximum correlation of $r \sim-0.49$ when the temperature was lagged by 1 year, indicating that we can explain at least $24 \%\left(r^{2} \sim 0.24\right)$ of the ice-front movement with the proxy variation of the warm Atlantic water. One caveat is that this is only a proxy for fjord temperature-if we had measurements of the actual temperature in the fjord near the Helheim glacier front over more than 30 years, the explanatory power may be substantially greater.

Then we also performed a similar cross-correlation analysis between the ice-front movement and SAT, finding a maximum correlation of -0.75 when lagged 2 years, thereby accounting for $56 \%$ of the ice-front movement $\left(r^{2} \sim 0.56\right)$. These statistics imply 
Fig. 7 Time series of the Helheim calving front position 1980-2010 in August/September (a), annual water temperature at $400 \mathrm{~m}$ depth in the Irminger Sea (b) and annual surface air temperature (SAT) 1970-2010 in Tasiilaq, southeast Greenland, 80-90 km east of the Helheim ice-front (c)
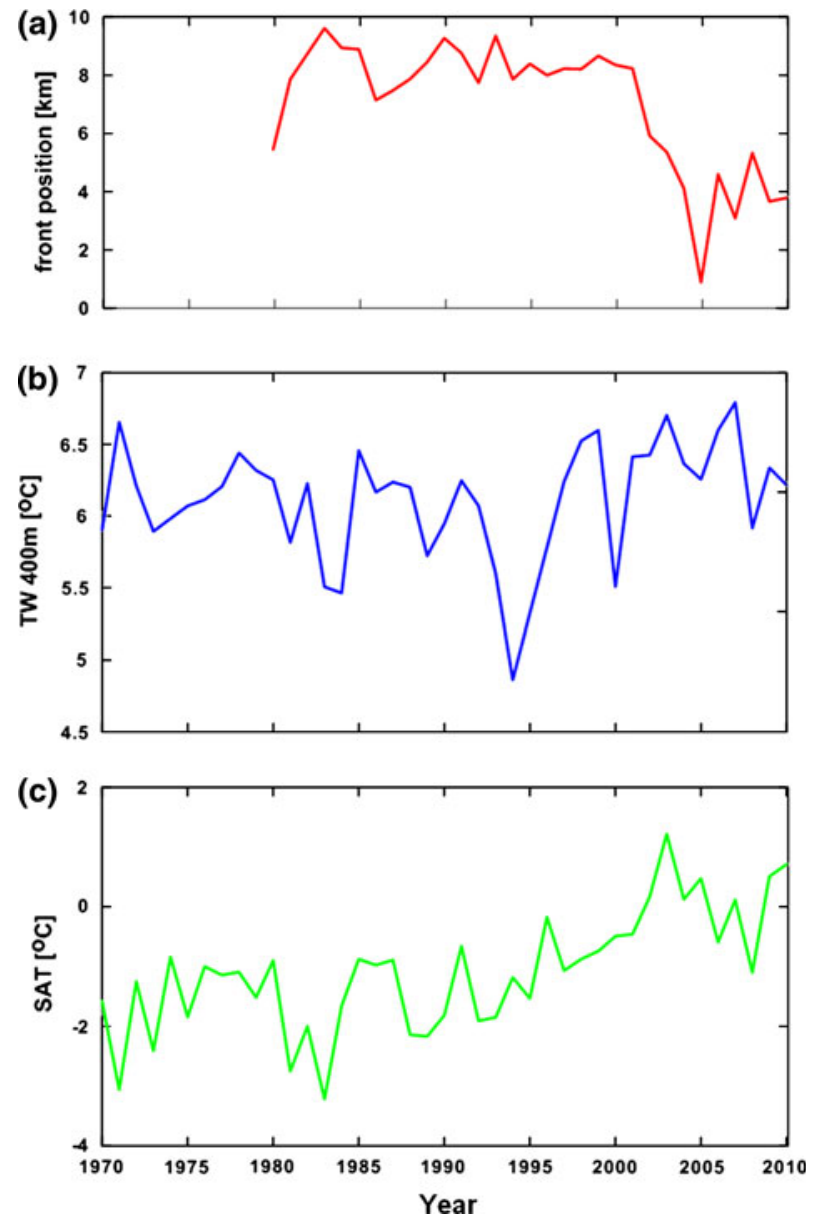

that the air temperature had more than twice the influence on the Helheim ice-front movement than did the ocean temperature. The effect of SAT on ice-front movement is through surface melting and subsequent downward percolation of meltwater through a huge number of crevasses in the Helheim glacier observed from a helicopter (Johannessen, pers. obs.), thereby leading to basal lubrication (e.g., Andersen et al. 2010; Schoof 2010) that may affect calving.

\subsection{Preliminary Conclusions}

1. The position of the Helheim glacier front appears to have been relatively stable from 1985 to 2001, varying only $1-2 \mathrm{~km}$; after 2001, the variations were larger, with a 6-7 km retreat in 2005 compared to the pre-2001 position.

2. Sermilik Fjord is "filled up" with warm, saline Atlantic Water below $250 \mathrm{~m}$ depth with temperature ranging from $1-4.5^{\circ} \mathrm{C}$, exposing the deeper part of Helheim glacier to warm water year-round. 
3. The greater retreating of the Helheim ice-front after 2000 coincides both with local surface air warming and enhanced warming in the Irminger Current of warm, saline Atlantic Water, which is found to penetrate into the Sermilik Fjord. Correlation analysis indicates that the variation of the SAT is more important than the variability of the ocean temperature for the movement of the ice-front. The precise contribution of air temperature versus ocean temperature, however, remains an open question, as more oceanographic and meteorological measurements are needed close to the glacier terminus, together with modeling efforts.

Acknowledgments We acknowledge funding from a donation by Trond Mohn c/o Frank Mohn As, Bergen and from the Nansen Scientific Society. Furthermore, we acknowledge the excellent performance of the crew onboard the sailboat Jotun Arctic. The lead author (OMJ) worked on this paper while as a "Visiting Professor for Senior International Scientists of the Chinese Academy of Sciences (CAS)" in OctoberNovember 2010 at the Institute of Atmospheric Physics, CAS, in Beijing.

Open Access This article is distributed under the terms of the Creative Commons Attribution Noncommercial License which permits any noncommercial use, distribution, and reproduction in any medium, provided the original author(s) and source are credited.

\section{References}

Andersen ML, Larsen TB, Nettles M, Elosegui P, van As D, Hamilton GS, Stearns LA, Davis JL, Ahlstrøm AP, de Juan J, Ekström G, Stenseng L, Khan SA, Forsberg R, Dahl-Jensen D (2010) Spatial and temporal melt variability at Helheim Glacier, East Greenland, and its effect on ice dynamics. J Geophys Res 115:F04041. doi:10.1029/2010JF001760

Bamber JL, Alley RB, Joughin I (2007) Rapid response of modern day ice sheets to external forcing. Earth Planet Sci Lett 257:1-13

Bindschadler R (2006) Hitting the ice sheets where it hurts. Science 311:1720-1721

Holland DM, Thomas RH, de Young B, Ribergaard MH, Lyberth B (2008) Acceleration of Jakobshavn Isbræ triggered by warm subsurface ocean waters. Nature Geosci 1:659-662

Howat IM, Joughin I, Scambos TA (2007) Rapid changes in ice discharge from Greenland outlet glaciers. Science 315:1559-1561

Howat IM, Joughin I, Fahnestock M, Smith BE, Scambos TA (2008) Synchronous retreat and acceleration of southeast Greenland outlet glaciers 2000-2006: ice dynamics and coupling to climate. J Glaciol 54:646-660

Johannessen OM (1968) Some current measurements in the Drøbak Sound, the narrow entrance to the Oslofjord. Hvalrådets skrifter. Det Norske Videnskaps-Akademi i Oslo. Oslo Universitetsforlaget: 38 p. ftp://ftp.nersc.no/OMJ/Joh68a.pdf

Johannessen OM, Babiker M, Miles MW (2011) Petermann Glacier, North Greenland: Massive calving in 2010 and the past half century. Cryosphere Discuss 5:169-181. www.the-cryosphere-discuss.net/5/ $169 / 2011$

Johnson HL, Münchow A, Falkner KK, Melling H (2011) Ocean circulation and properties in Petermann Fjord, Greenland. J Geophys Res 116:C01003. doi:10.1029/2010JC006519

Joughin I, Abdulati W, Fahnestock M (2004) Large fluctuations in speed on Greenland's Jakobshavn Isbræ glacier. Nature 432:608-610

Joughin I, Howat I, Alley RB, Ekstrom G, Fahnestock M, Moon T, Nettles M, Truffer M, Tsai VC (2008) Ice-front variation and tidewater behavior on Helheim and Kangerdlugssuaq Glaciers, Greenland. J Geophys Res 113:F01004. doi:10.1029/2007JF000837

Mernild S, Howat IM, Ahn Y, Liston GE, Steffen K, Jakobsen BH, Hasholt B, Fog B, van As D (2010) Freshwater flux to Sermilik Fjord, SE Greenland. The Cryosphere 4:453-465

Murray T, Scharrer K, James TD, Dye SR, Hanna E, Booth AD, Selmes N, Luckman A, Hughes ALC, Cook S, Huybrechts P (2010) Ocean regulation hypothesis for glacier dynamics in southeast Greenland and implications for ice sheet mass changes. J Geophys Res 115:F03026. doi:10.1029/2009JF001522

Nick F, Vieli A, Howat IM, Joughin I (2009) Large-scale changes in Greenland outlet glacier dynamics triggered at the terminus. Nature Geosci 2:110-114 
Rignot E, Kanagaratnam P (2006) Changes in the velocity structure of the Greenland Ice Sheet. Science 311:986-990

Rignot E, Steffen K (2008) Channelized bottom melting and stability of floating ice shelves. Geophys Res Lett 35:L02503. doi:10.1029/2007GL031765

Schoof C (2010) Ice-sheet acceleration driven by melt supply variability. Nature 468:803-806. doi: 10.1038 /nature09618

Straneo F, Hamilton GS, Sutherland DA, Stearns LA, Davidson F, Hammill MO, Stenson GB, Rosing-Asvid A (2010) Rapid circulation of warm subtropical waters in a major glacial fjord in East Greenland. Nature Geosci 3:182-186

Truffer M, Fahnestock M (2007) Rethinking ice sheet time scales. Science 315:1508-1510

Zwally HJ, Abdalati W, Herring T, Larson K, Saba J, Steffen K (2002) Surface melt-induced acceleration of Greenland ice-sheet flow. Science 297:218-222 